\title{
BY THE THIRD MOJITO AND OTHER POEMS
}

\author{
Noelle Leslie dela Cruz \\ De La Salle University (Manila) \\ avalon.rain@gmail.com
}

\begin{abstract}
About the Author
Noelle Leslie dela Cruz is an Associate Professor of Philosophy at De La Salle University, Manila, where she received her Ph.D. in Philosophy and her Master of Fine Arts in Creative Writing. In 2009, her poem "Discourse" won First Prize in the Philippines Free Press Literary Awards. She co-edited an anthology of essays entitled Feminista: Race, Class, and Gender in the Philippines, published by Anvil in 2011. She is also the book review editor for the widely abstracted Filosophia: The International Journal of Philosophy. Her most recently completed research is an unpublished manuscript on the hermeneutical phenomenology of sequential art. She is currently at work on a study about Jan Zwicky's lyric philosophy as a framework for seeing how poems (as poems, not as propositional paraphrase) can be said to philosophize.
\end{abstract}




\section{BY THE THIRD MOJITO}

The genie is out of the bottle and I don't know who is speaking for whompuppet or ventriloquist, clasped hands

or shadow dog on the wall, fingers spreading to become dove. I'm speaking in tongues, huddling with apostles, licks of flame

taking the place of speech bubbles. I am the brightest candle at the party, talking philosophy like Plato planting

rumors of sunlight in Socrates' mouth. I smile serenely beneath the ice, imagining people imagine me as Ophelia

by way of Waterhouse, a floater contemplating the transience of clouds. My professor says the Self is less like

an avocado than an artichoke. We'll get back to that. I'm enjoying myself too much for the instruction of metaphor, reciting a poem

by popular demand. In the sudden silence she unravels herself like a well-read scroll. They listen avidly for the final verse

awaiting the big reveal, the core of story or the point of peeling. I can only tell you how the striptease feels like

from the inside, astonishing archeologists digging in the ruins: Freedom is knowing that under the last layer lies so much nothing. 


\title{
WRITER'S BLOCK
}

\begin{abstract}
"Some cuttlefish, and a few octopuses, go through an almost continual, kaleidoscopic process of color change that appears disconnected from anything going on outside them, and appears instead to be an inadvertent expression of the electrochemical tumult inside them."

-Peter Godfrey-Smith, Other Minds
\end{abstract}

It had been weeks of poetry classes. Some afternoons I spent just sleeping on the couch, pretending to be inside a cocoon, dreaming of a butterfly future. My body was asleep and so were my fingers, my mouth. And then I saw a video clip of a cuttlefish in varying stages of camouflage. It was a small animal, its surfer board body capped by a prominent head, from which spewed a waterfall of arms. It was in a laboratory where scientists tried changing the backdrop, from a fine sandy field to one with a checkerboard pattern. In each instance, I watched its skin transform into a surface of glyphs. The second time, the ruse was not so good; though it mimicked its surroundings, you could still see its soft round body, plainly outlined, like a text with a standard reading. I figured the sudden ineptness was due to its recent displacement, a diaspora-like loss. I imagined it longing for the comfort zone of all its meanings. I wished they would put it back where it belonged, safe from predators as it blended into the seaweed or coral. But they wanted to perform their tests, to learn the secret of cuttlefish adaptation, its ability to disappear by becoming the world around itself. I both envied and pitied it, this mollusk whose poetry needed no words. How liberating must it be, for all that iridescence to be enough? And yet how painful, how confusing must it be, for one's genius suddenly to serve no purpose? 


\section{ORPHEUS TO EURYDICE}

Love, how night can swarm Into a room when you leave it, the light switch making too much noise. The day that cannot be wholly recalled is finally over. I trudge to bed, a choreography of stairs, past miles and miles of stalactites, the cave's ferocious teeth gleaming in the moonlight, feeling again Cerberus' breath upon my neck. Now

I am not looking over my shoulder at a half-invented past. I am not looking for an exit, but for the shortest path toward that other awakening. That is to say, the mind's negotiations with night, a net whose holes are big enough for live things to slip through, tearing the delicate threads of our speech and patchwork days. And then

you are there, gathering pieces of myself, the un-tattered, un-torn me I say goodbye to everyday, so we may meet again, like this, so I can forgive you for always leaving. So tomorrow comes the possibility of song. 


\section{SERENDIPITY}

My foot slipped on the stair step.

After too much wiping, the wood gleamed

with the worry of attentive labor

by the well-meaning house help.

I am teaching her to write. Her brows

knit each time I see her these days

as I await her book report

on The Little Prince. In a parallel world

as privileged accidents go

I tumbled down, broke my hip, spent the rest of my days bedridden

fractures of self gathering

toward each other, possessed

by the memory of original unity.

In the wisdom of Leibniz's monads, in this best of all possible worlds, my fingers caught the railing in time.

Writing lessons are connected

to the traction of perspiration,

to the choreography of instinct:

that constant buzzing beneath

the river of language, to which

we owe our perception of grace,

our imagination of what the fox saw

when he said what was essential

was invisible. I think of her bent head

as she mulled over my questions,

about her favorite planet

in the little prince's itinerary.

What serendipity-look up this word-

put him in the stranded pilot's path

at exactly that spot in the desert? 
In that other universe, I could be unconscious at the bottom of the stairs. Perhaps I never went to college, and this poem was never written.

But I'm not, I did, and it was. 